\title{
ÄTTEN BERNADOTTE OCH SVENSK KRIMINALVÅRD
}

\section{AV PROFESSOR LARS LIDBERG}

Fångelsestraffet, i den form vi förstår det i dag, infördes ursprungligen i upplysningstidens Frankrike och kom till Sverige med Carl XIV Johan (1818-1844). Det infördes mer systematiskt i Sverige som strafform av hans son, Oskar I. Tanken bakom fängeslestraffet hänger samman med föreställningen att man kan mäta den onda viljan hos brottslingen, hans skuld och därigenom skapa en rättvis påföljd, en tanke som funnits hos oss endast i omkring tvåhundra år.

Idén bakom fängelsestraffet, i form av cellstraff, var att fångarna skulle genomgå ett slags psykoterapi. Denna psykotarepi skulle ske enskilt, mellan fången och Gud. Ensam med en andaktsbok och Bibeln skulle han begrunda sina fel och brister, han skulle komma till en slags frälsning. Gud och hans egna inre, starka krafter skulle hjälp honom att förändra livet och vända det till något nytt och bättre.

Det är i dagens perspektiv intressant att se hur debatten för 100 år sedan mellan olika kriminalvårdsföreträdare hade samma hetta och styrka som nu. Vilket var bäst? Den totala ensamheten i cellen eller den ensamma tillvaron på natten och det tysta arbetet i stenbrottet under dagtid? Goda empiriska, uppföjande undersökningar saknades då, och saknas i stor utsräckning även i dag. Vår syn på fängelsetraffet är att det bör aktivera den dömde. Vi vet att isolering är av ondo, det bryter ned. Vi försöker bygga säkra fängelser, men med möjlighet till arbete och sysselsättning inom fängelsets ramar.

Vid 1800-talets början fanns dödsstraff vid allvarliga brott. Ett sådant brott var ordervägran inför fienden i krig. Tillämpningen av dödsstraffet under Sveriges två sista krig är av särskilt intresse. Dessa krig utkämpades 1809 respektive 1815, det första i Finland mot Ryssland och det andra var det gemensamma fälttåget i Tyskland mot Napoleon. I båda krigen utmättes flera dödsstraff.

Under det första kriget, det mot Ryssland, blev de verkställda. Under det andra kriget blev en så berömd man som Georg Carl von Döbeln, segraren vid Jutas, dömd till döden för ordervägran. Straffet verkställdes dock aldrig, det omvandlades till fängelse och han fick avtjäna tiden på Vaxholms fästning. Så blev även fallet med andra dödsstraff som utmättes under kriget 1815. Rättstillämpningen skilde sig med andra ord mycket mellan de två så näraliggande krigen. Detta berodde på att överbefälhavaren omvandlade dödsstraffen till fängelse. Endast överbefälhavaren, eller överstekrigsherren som det då hette, hade denna befogenhet att bevilja leuteration, att nedsätta straff. Vem var då överbefälhavare i kriget 1815? Jo, det var den nye tronfö 1 jaren, marskalken av Frankrike Carl Johan Bernadotte, vald till tronföljare, sedermera Carl XIV Johan. Han förde med sig de nya tankegångarna från sitt hemland. Han ville ej låta 
dödsstraffen gå i verkställighet. Förutom upplysningsidéerna, hade man i Frankrike även en uppfattning att de, som vågat sitt liv för fosterlandet, inte skulle vanhedras eller förnedras genom gatlopp eller prygel.

Carl XIV Johans son, Oskar I, tog livlig del i straffrätten och debatten kring denna. Han skrev en bok som kallades för "Gula Boken" efter sitt gula omslag. Möjligen var det förste chefen för fångvården, Clas Livijn, som skrev boken, men den var i kungens anda och många trodde att kungen själv skrivit den gula boken. Här förordades helt nya och helt andra strafformer - cell fängelser skulle uppföras. Idén om cellfängelset hade sitt ursprung i religionen, den kom från kväkarna i USA. Deras stamort var Philadelphia och fängelsesystemet kom att kallas för Philadelphia-systemet. I nästan varje residensstad byggdes nya fängelser till stora kostnader, på väl synliga platser, med celler där fångarna hölls isolerade från varandra. Än i dag kan vi se dem, monumentalt belägna - några har fått användning som hotell eller teater.

Det var höga kostnader som staten tog på sig med fängelsebyggandet, trots att man förlorat halva landet, Finland, till den stora grannen i öster.

Tanken med cellstraffet var alltså att den dömde inför Gud och sitt samvete skulle begrunda sin skuld i ensamhet och få en religiös omvändelse. Utan påverkan från andra fångar kunde han studera Bibeln, psalmboken, en betraktelsebok av Salvén och andra, religiösa böcker. Andra böcker var inte tillåtna. Principen att isolera fångarna från varandra drevs så långt att celldörrarna stod förskjutna i sidled i förhållande till varandra. Om en fånge öppnade sin dörr skulle han inte kunna se sin medfånge över det stora galleriet. I kyrkan satt fångarna i enskilda kabinett och kunde endast se prästen. De långa öppna gallerierna i mitten kan vi alltjämt se i fängelser från amerikanska filmer. I Sverige kallades de bottnar och omgärdades av gallerstaket - kanske skulle de i ett annat hus ha kallats atrier?

Det största fängelset, och främsta förbilden enligt Philadelphia-systemet, var det väldiga Eastern Penitentiary (Östra Fängelset) i Philadelphia. Penitentiary kommer just av det engelska ordet förbot.

Så småningom insåg man att fångarna inte mådde bra av att sitta ensamma, isolerade i sina celler. De skulle arbeta under tystnad på dagarna, men fortfarande vara ensamma i sina celler nattetid. Man byggde en ny typ av fängelser, enligt det så kallade Auburnsystemet, efter en ort i USA där det först byggdes. Cellerna byggdes runt ett större rum / en gård, med cellerna vända inåt mot mitten av byggnaden, där fångarna kunde arbeta dagtid, under tystnad. Än i dag kallas ju fängelset för "stillot", en zigensk term som anspelar på den tystnad som skulle råda. Författaren minns tydligt hur man i Långholmsfängelset ropade "tyst i fängelset"! Det mest kända Auburnfängelset blev Sing-Sing. I Sverige fanns en unik kombination i form av Långholmsfängelset, byggt delvis enligt Philadelphia-systemet, delvis enligt Auburn-modellen. Det gamla centralfängelsets Philadelfiadel användes länge som häkte. Kriminologerna vid denna tid diskuterade livligt, lika livligt som i dag vilken påföljd som var den bästa och 
den mest "effektiva".

I vackra, graverade guldprydda böcker i Kungliga Bibliotekets arkiv kan fängelser från olika delar av världen studeras. Här finns nämligen en unik samling rikt utstyrda böcker med kungliga monogram, böcker som innehåller skisser av fängelser i olika utföranden, fängelser från Ryssland, England och Amerika. Som ett kuriosum, finns även kartor över Australien, det land dit England deporterade sina förbrytare.

Hur kan då denna, $\mathrm{i}$ flera bemärkelser så imponerande samling fängelsebeskrivningar ha hamnat i Kungliga Biblioteket? Jo, den utgör gåvor, främst till Oskar I:s son, kung Carl XV. Han var känd för att privat leva på stor fot, med ekonomiska konsekvenser. När han dog, beviljade Riksdagen medel för att hjälpa dödsboet, kanske undan konkurs. Detta skedde dock endast mot kompensation i form av den vackra boksamlingen, som tidigare varit familjen Bernadottes privata. Den förgyllda boksamlingen överlämnades till Kungliga Biblioteket, där den är väl bevarad och väl värd att studera.

Genom sitt intresse och sina insatser för straffsystemets och fängelseväsendets förändring kom således de första Benadotterna på Sveriges tron att kraftfullt bidra till att förbättra fångvården och villkoren för fångarna i Sverige - deras insatser kan också ses som ett försök att minska brottsligheten i Sverige.

I dag, när vi ser hur inflytelserika politiker, såvä1 i Sverige som utomlands, söker vända utvecklingen och hör dem tala för hårdare villkor för fångarna och längre strafftider - även "livstidsstraff vid tredie resan" - undrar man vem i dagens, demokratiska statsledning som skulle kunna bidra med positiva visioner och förbättra förhållandena för dagens fångar? Vem kan i dag tänka sig att stå upp för ett bättre och mer meningsfullt innehåll i straffet (för både sjuka och friska) i dagens fångvård / kriminalvård, i ett försök att minska brottsligheten?

$\mathrm{Nu}$ långt mer än 100 år efter fängelsets yttre formförändring och cellfängelsets tillkomst är det ett stort ansvar att gå vidare med nästa steg, att äntligen ge fängelsevistelsen ett bättre och mer individuellt anpassat innehåll till hjälp att förändra livet för de intagna och minska brottsligheten i samhället. Vem skall vi uppvakta med praktband och ritningar till en bättre framtid på datadiskett eller CD-romskiva i förgyllt omslag?

Adresse: Engelbrektsgaten 13

SE - 11432 Stockholm 